
Institut für Lebensmittelsicherheit und -hygiene der Vetsuisse-Fakultät Universität Zürich
Direktor: Prof. Dr. Roger Stephan

Arbeit unter Leitung von PD Dr. Claudio Zweifel

\title{
Phenotypic and molecular typing of Listeria monocytogenes isolated from the processing environment and products of a sandwich- producing plant
}

\author{
Inaugural-Dissertation \\ zur Erlangung der Doktorwürde der \\ Vetsuisse-Fakultät Universität Zürich \\ vorgelegt von \\ Simona Blatter \\ Tierärztin \\ von Niederried bei Interlaken, Schweiz
}

genehmigt auf Antrag von

Prof. Dr. Roger Stephan, Referent

Prof. Dr. Maria Fredriksson-Ahomaa, Korreferentin

Zürich 2010 

Meinen Eltern

In grosser Dankbarkeit und Liebe 



\section{CONTENTS}

1. Abstract 3

2. Introduction 4

3. Materials and Methods 5

3.1. Food-processing plant and sampling 5

3.2. Listeria detection and identification 6

3.3. Characterization of L. monocytogenes strains 6

4. $\quad$ Results $\quad 7$

4.1. $\quad$ Prevalence and distribution of Listeria 7

4.2. Characterization of L. monocytogenes strains 8

$\begin{array}{lll}5 . & \text { Discussion } & 9\end{array}$

$\begin{array}{ll}\text { 6. } & 12\end{array}$

$\begin{array}{lll}\text { 7. Tables } & 17\end{array}$

8. Acknowledgements 20 
Phenotypic and molecular typing of Listeria monocytogenes isolated from the processing environment and products of a sandwich-producing plant

Simona Blatter, Nicole Giezendanner, Roger Stephan, Claudio Zweifel*

Institute for Food Safety and Hygiene, Vetsuisse Faculty University of Zurich, 8057 Zurich, Switzerland

*Corresponding author. Phone: +41-44-635-8651; fax: +41-44-635-8908. E-mail address: ils@fsafety.uzh.ch (C.Zweifel).

Accepted for Publication, Food Control, Elsevier, Amsterdam, The Netherlands

In fulfillment of the doctoral thesis of Simona Blatter 


\section{Abstract}

Listeria monocytogenes as a food-borne pathogen has significant public health and economic impacts. The present study investigated the diversity of L. monocytogenes in a Swiss sandwich-producing plant over a 12-month period. L. monocytogenes were detected by culture after enrichment in $70(3.5 \%)$ of 2'028 environmental swabs and $16(7.4 \%)$ of 217 samples from ingredients and sandwiches. Of the 86 L. monocytogenes strains, 93\% belonged to serotype 1/2a and genetic lineage II. Rep PCR and PFGE analysis yielded each six profiles. Sixty-seven $(77.9 \%)$ strains belonged to only one genotype, which was repeatedly found on/in slicers, conveyor belts, tables, a breadfeeding machine, spattles, air blow-guns, salmon, and egg sandwiches. Strains of this genotype persisted for more than nine months in the processing environment, in particular on slicers and conveyor belts, which probably contributed to the contamination of sandwiches. After revision of the cleaning and disinfection procedures, L. monocytogenes were no longer found on slicers, conveyor belts, or in products. Besides, these results emphasize the importance of environmental monitoring schemes to identify potential contamination sources and as an early warning system for food business operators.

\section{Keywords:}

Listeria monocytogenes; Genetic diversity; Persistence; Ready-to-eat food-processing plant; Sandwiches 


\section{Introduction}

Listeria (L.) monocytogenes as a food-borne pathogen has significant public health and economic impacts. Human infections primarily result from eating contaminated food and may lead to serious and potentially life-threatening listeriosis. Pregnant women, neonates, elderly, or immunocompromised people are particularly susceptible to listeriosis, which typically presents as septicemia, meningitis, or meningoencephalitis (Doganay, 2003; Vázquez-Boland et al., 2001). Because of its high case fatality rate, listeriosis ranks among the most frequent causes of death due to food-borne illness (CDC, 2009; Mead et al., 1999; Swaminathan \& Gerner-Smidt, 2007). Reports show that L. monocytogenes infections are responsible for high hospitalization rates and have been linked to sporadic episodes and large outbreaks (Jemmi \& Stephan, 2006; Varma et al., 2007; Warriner \& Namvar, 2009). In the European Union (EU), a total of 1'381 confirmed human cases of listeriosis (0.3/100'000) have been reported in 2008 (EFSA, 2010). In several states of the EU, the annual incidence rate has thereby increased over the last few years, especially in the elderly population.

Furthermore, L. monocytogenes is of great economic relevance for food business operators because contamination of food products might result in large recalls and changed buying behavior of consumers (CDC, 2002; Jemmi \& Stephan, 2006; Wong, Street, Delgado, \& Klontz, 2000). Amongst other foods, ready-to-eat products have recently often been implicated in recalls and outbreaks (CDC, 2002; Dawson, Evans, Willby, Bardwell, Chamberlain, \& Lewis, 2006; Swaminathan \& Gerner-Smidt, 2007). Thereby, the ability of L. monocytogenes to persist in food-processing environments and to grow at low environmental temperatures present major challenges for the food industry and food safety (Tasara \& Stephan, 2006; Warriner \& Namvar, 2009).

According to the EU food safety legislation the onus of compliance is placed on food business operators, which must apply compulsory self-checking programs following the hazard analysis critical control point (HACCP) approach and must ensure that their food products meet the regulatory requirements. Thus, Regulation (EC) No. 2073/2005 sets out microbiological criteria for food-borne pathogens on foodstuffs (Anonymous, 2005). Moreover, this regulation requires manufacturers of ready-to-eat foods to examine the processing environment for L. monocytogenes as part of their sampling schemes. 
Such examinations along with data from food products form the basis to monitor the L. monocytogenes situation in a food-processing plant. In the present study, we investigated the occurrence and genetic diversity of Listeria monocytogenes in a Swiss sandwich-producing plant over a 12-month period. The aim was to evaluate the potential persistence of L. monocytogenes in the processing environment and to identify possible contamination sources and routes for food products.

\section{Materials and Methods}

\subsection{Food-processing plant and sampling}

This study was based on investigations carried out within 12 months (November 2008 to November 2009) in a ready-to-eat food-processing plant. In the processing room of this plant, five sandwich production lines were located. Weekly, 48'000 sandwiches were produced. Packaged sandwiches were distributed to retail shops throughout Switzerland.

To evaluate the occurrence of Listeria and especially L. monocytogenes, 1'192 samples from the equipment of the sandwich processing lines (e.g. slicers, knives, or conveyor belts), 307 samples from the environment (e.g. drains, walls, or floors), and 217 samples from ready-to-eat ingredients pre-handled in the plant (e.g. salmon, ham, or salami sliced in the examined plant) and sandwiches (e.g. tuna, salmon, meat, or egg sandwiches) were collected during the working process. Additionally, 529 samples from the equipment and environment were obtained after cleaning and disinfection. Sampling comprised two phases. The distribution of samples in the first sampling phase (November 2008 to July 2009) is shown in Table 1. In the second sampling phase (October to November 2009), 249 samples from the equipment $(n=207)$ and environment $(n=42)$ collected after cleaning and disinfection, and 29 samples from ingredients and sandwiches (final products) were investigated. The aim of the first phase was to evaluate the basic situation and the potential persistence of L. monocytogenes strains in this plant, whereas the second phase evaluated the effect of revised cleaning and disinfection procedures and focused on identified problem areas. Sampling was performed twice a week and comprised about 80 samples per visit. 
Samples from the equipment and environment were collected with cotton swabs. From ingredients and final products, $25 \mathrm{~g}$ were collected in each case. Samples were subsequently placed into cool boxes and microbiological examinations were carried out within $4 \mathrm{~h}$ after sampling.

\subsection{Listeria detection and identification}

Examinations for Listeria were performed using a two-step enrichment procedure. Each swab was incubated for $24 \mathrm{~h}$ at $30{ }^{\circ} \mathrm{C}$ in $20 \mathrm{ml}$ of Half-Fraser broth (Oxoid Ltd., Hampshire, United Kingdom). Ingredient and final product samples were incubated for $24 \mathrm{~h}$ at $30^{\circ} \mathrm{C}$ in $225 \mathrm{ml}$ of Half-Fraser broth (Oxoid Ltd.). A subset of $0.1 \mathrm{ml}$ was then incubated in $10 \mathrm{ml}$ of Fraser broth (Oxoid Ltd.) for $24 \mathrm{~h}$ at $37{ }^{\circ} \mathrm{C}$. Subsequently, subsets were plated onto Palcam agar (Merck Eurolab GmbH, Darmstadt, Germany), which were then incubated for $48 \mathrm{~h}$ at $37{ }^{\circ} \mathrm{C}$. Listeria-like colonies were streaked onto Oxoid Chromogenic Listeria Agar (Oxoid Ltd.) supplemented with Listeria Selective Supplement and Listeria Differential Supplement (Oxoid Ltd.) and incubated for $48 \mathrm{~h}$ at $37{ }^{\circ} \mathrm{C}$. Presumptive $\mathrm{L}$. monocytogenes colonies on the chromogen agar were streaked onto sheep blood agar (Oxoid Ltd.) for appraisal of hemolysis. To identify other Listeria species, the API Listeria Identification Kit was used (bioMérieux SA, Geneva, Switzerland) in accordance with the manufacturer's instructions.

\subsection{Characterization of L. monocytogenes strains}

Isolated L. monocytogenes strains were characterized by serotyping, determination of genetic lineages, repetitive element PCR (Rep PCR) typing, and pulsed-field gel electrophoresis (PFGE) analysis. Serotyping was performed at the Swiss National Center for Listeriosis (Lausanne, Switzerland). For the determination of genetic lineages, the ASO-PCR multiplex system targeting the prfA virulence gene cluster was applied (Ward, Gorski, Borucki, Mandrell, Hutchins, \& Pupedis, 2004). Based on phylogenetic analysis, L. monocytogenes is separated into three genetic lineages (Liu et al., 2006). Rep PCR was performed as described by Jeršek et al. (1999). 
Thereby, the repetitive extragenic palindrome was amplified using forward primer REP1R-I (5-IIIICGICGICATCIGGC-3) and reverse primer REP2-I1 (5ICGICTTATCIGGCCTAC-3). Furthermore, L. monocytogenes were characterized by PFGE following the CDC PulseNet protocol (http://www.cdc.gov/pulsenet/protocols.htm) and modifications in accordance with Benjamin and Datta (1995). Briefly, colonies from blood agar were resuspended in cell suspension buffer $\left(\mathrm{OD}_{610}=1.3\right)$. For plug preparation, $300 \mu \mathrm{l}$ of cell suspensions were mixed with $300 \mu \mathrm{l}$ of $1.2 \%$ chromosomal grade agarose (Bio-Rad Laboratories, Basel, Switzerland) and cells were lysed by lysozyme and proteinase $\mathrm{K}$ treatment. After washing with Tris-EDTA buffer, DNA agarose plugs were incubated over night in the presence of ApaI (Promega, Madison, Wis., USA) following the manufacturer's instructions. Macrorestriction fragments were separated in $1 \%$ pulsed field certified agarose gel at $6 \mathrm{~V} / \mathrm{cm}$ in $10 \mathrm{X}$ Tris-Borate-EDTA buffer cooled to $14{ }^{\circ} \mathrm{C}$ in a CHEF-DR III system (Bio-Rad Laboratories). The pulse times were ramped from 4 to $40 \mathrm{~s}$ for $19 \mathrm{~h}$ and an angle of $120^{\circ}$. Gels were stained with ethidium bromide and visualized under UV light transillumination with Gel Doc (Bio-Rad Laboratories).

\section{Results}

\subsection{Prevalence and distribution of Listeria}

Of the 1'779 equipment and environmental samples collected in the first sampling phase (November 2008 to July 2009), 65 (3.7\%) were positive for Listeria spp. (Table 1). The 60 Listeria isolates collected during the working process were identified as L. monocytogenes (59 strains) and Listeria welshimeri (one strain), whereas the five Listeria isolates collected after cleaning and disinfection were identified as $L$. monocytogenes. The origin of the $64 \mathrm{~L}$. monocytogenes strains is shown in Table 2. Thereby, 28 strains $(43.8 \%)$ originated from three slicers, which tested repeatedly positive. Besides, in the second sampling phase (October to November 2009), six (2.4\%) of the 249 samples collected from the equipment and environment after cleaning and disinfection were positive for Listeria spp. Positive samples were thereby only detected during the first two visits. 
All six isolates were identified as L. monocytogenes and originated from a breadfeeding machine repeatedly testing positive, a water hose, and a drain (Table 2).

Furthermore, $22(11.7 \%)$ of the 188 samples from pre-handled ingredients and final products collected in the first sampling phase tested positive for Listeria spp. (Table 1), whereas Listeria spp. were not detected among the 29 samples collected in the second sampling phase. Of the 22 Listeria isolates, 16, 4, 1, and 1 were identified as L. monocytogenes, L. welshimeri, L. seeligeri, and L. innocua, respectively. The $16 L$. monocytogenes strains originated from sliced salmon, sliced ham, tuna sandwiches, egg sandwiches, and meat sandwiches (Table 3), whereas L. welshimeri, L. seeligeri, and L. innocua were only found in sliced salmon.

\subsection{Characterization of L. monocytogenes strains}

Of the $64 \mathrm{~L}$. monocytogenes strains obtained from the equipment and environment in the first sampling phase (during the working process and after cleaning and disinfection), 61 belonged to serotype $1 / 2 \mathrm{a}$ and genetic lineage II, whereas the remaining three strains belonged to serotype $1 / 2 b$ and genetic lineage I (Table 2). The six L. monocytogenes strains obtained from the equipment and environment in the second sampling phase (after cleaning and disinfection) belonged to serotype 1/2a and genetic lineage II. Of the $16 \mathrm{~L}$. monocytogenes strains obtained from ingredients and final products, 13 belonged to serotype $1 / 2$ a and genetic lineage II, and three belonged to serotype $1 / 2 \mathrm{~b}$ and genetic lineage I (Table 3 ).

Genotyping of all the 86 isolated L. monocytogenes strains yielded six different patterns using Rep PCR typing (a to f) and six different patterns using PFGE analysis (A to F). The $64 \mathrm{~L}$. monocytogenes strains obtained from the equipment and environment in the first sampling phase comprised three different genotypes (Table $2)$, and the great majority ( $84.4 \%$ ) of them belonged to only one genotype (a, A). All 48 strains obtained from the equipment of the processing lines belonged to the predominant genotype $(\mathrm{a}, \mathrm{A})$. Strains of this genotype were thereby repeatedly found on slicers, conveyor belts, tables, and spattles. The 16 strains obtained from the environment comprised three different genotypes ( $a, A ; b, B$; c, C). Thereby, strains from water hoses, air blow-guns, and floors repeatedly belonged to a certain of these genotypes. 
Besides, the six L. monocytogenes strains obtained from the equipment and environment in the second sampling phase (after cleaning and disinfection) belonged to two different genotypes (a, A; c, C) (Table 2). Thereby, the four strains from the bread-feeding machine belonged to the predominant genotype (a, A). Furthermore, the $16 \mathrm{~L}$. monocytogenes strains obtained from ingredients and final products comprised five different genotypes (Table 3). More than half of these 16 strains belonged to only one genotype (a, A).

\section{Discussion}

In the examined sandwich-producing plant, L. monocytogenes were detected within 12 months in $3.5 \%$ of the samples obtained from the equipment and environment during the working process and after cleaning and disinfection. Besides, L. monocytogenes were also found in ingredients pre-handled in the examined plant and in final products. Salmon sliced in the plant, and sandwiches (tuna, egg, and meat) thereby tested repeatedly positive. In previous studies, fish and seafood have been identified as foods frequently contaminated with L. monocytogenes (Jemmi, Pak, \& Salman, 2002; Rørvik, Aase, Alvestad, \& Caugant, 2000). Similarly, L. monocytogenes are found in sandwiches, which have also been associated with outbreaks in the United Kingdom (Dawson et al., 2006; Little, Barrett, Grant, \& McLauchlin, 2008; Little, Sagoo, Gillespie, Grant, \& McLauchlin, 2009; Pesavento, Ducci, Nieri, Comodo \& Lo Nostro, 2010; Wilson, 1996). However, data, especially characterization data of L. monocytogenes from sandwich-producing plants were so far scarce in literature.

The great majority (93\%) of the 86 L. monocytogenes strains isolated in the present study from the processing environment, ingredients, and final products belonged to serotype $1 / 2 \mathrm{a}$ and genetic lineage II. Based on phylogenetic analysis, genetic lineage II covers serovars 1/2a, 1/2c, 3a, and 3c (Liu et al., 2006). Strains of serotype $1 / 2$ a are frequently found in food products (Little et al., 2009; Swaminathan \& Garner-Smidt, 2007; Varma et al., 2007). 
The majority of human cases are associated with L. monocytogenes of serotypes $1 / 2 a, 1 / 2 b$, and $4 b$ and the proportion associated with strains of serotype $1 / 2 \mathrm{a}$ has increased in recent years (Allerberger \& Wagner, 2010; Lukinmaa, Miettinen, Nakari, Korkeala, \& Siitonen, 2003; Parihar et al., 2008).

Genotyping of L. monocytogenes of this strain collection by Rep PCR and PFGE analysis resulted in a comparable discriminatory power and each method yielded six different patterns (Rep PCR profiles a to f, PFGE profiles A to F). Both methods have been successfully applied in previous studies for typing of L. monocytogenes (Brosch, Brett, Catimel, Luchansky, Ojeniyi, \& Rocourt, 1996; Chou \& Wang, 2006; Jeršek et al., 1999). In the present study, $82.9 \%$ of the 70 strains isolated from the processing environment and more than half of the 16 strains isolated from ingredients and final products belonged to only one genotype (Rep PCR profile a, PFGE profile A). Strains of this genotype were repeatedly found in samples from slicers, conveyor belts, tables, a bread-feeding machine, spattles, air blow-guns, salmon sliced in the plant, and egg sandwiches. The second most common genotype (Rep PCR profile c, PFGE profile C) comprised nine strains from the processing environment and three strains from final products. Strains of this genotype were repeatedly found in samples from floors and tuna sandwiches. Thereby, L. monocytogenes of these two predominant genotypes (a, A; c, C) were obtained from the processing environment in both sampling phases and both during the working activity and after cleaning and disinfection. Interestingly, half of the six L. monocytogenes strains from water hoses belonged to a genotype not detected in other samples, and these were the only environmental strains belonging to serotype $1 / 2 b$ and genetic lineage $I$.

Overall, L. monocytogenes of two predominant genotypes persisted for more than nine months in the processing environment of the examined plant ("in-house-flora"). This emphasizes the ability of certain L. monocytogenes strains to become established in the processing environment (Martinez et al., 2003; Norton, McCamey, Gall, Scarlett, Boor, \& Wiedmann, 2001; Wulff, Gram, Ahrens, \& Fonnesbech-Vogel, 2006). Persistence thereby might be related to differences between strains in terms of biofilm production or cold stress adaption (Di Bonaventura et al., 2008; Nufer, Stephan, \& Tasara, 2007). 
The finding of corresponding genotypes in the processing environment, prehandled ingredients (e.g. salmon sliced in the plant), and sandwiches in the present study shows that the processing environment might contribute to the contamination of products, as it has been demonstrated before for other foods, especially for seafood (Lin et al., 2006; Martinez et al., 2003; Norton et al., 2001; Wulff et al., 2006).

The repeated finding of corresponding genotypes on certain localizations in the examined plant allowed the identification of plant-specific problem areas. In the first sampling phase (nine months), matching genotypes were repeatedly found on various localizations, but in particular on slicers and conveyor belts. On this equipment, corresponding genotypes were detected on repeated occasions and both during the working process and after cleaning and disinfection. Due to their construction, slicers or conveyor belts are often difficult to clean and maintain adequately and therefore constitute probable contamination sources for food products (Lin et al., 2006; Sheen \& Hwang, 2008; Tolvanen, Lundén, Hörman, \& Korkeala, 2009; Vorst, Todd, \& Rysert, 2006). Moreover, air blow-guns and water hoses testing repeatedly positive for strains of certain genotypes might indirectly contributed to the contamination of food products by the hands of employees (Kerr, Birkenhead, Seale, Major, \& Hawkey, 1993; Martinez et al., 2003; Montville, Chen, \& Schaffner, 2001). Based on the data from the first sampling phase, cleaning and disinfection procedures of the plant were revised with a main focus on identified problem areas, including enhanced supervision by the quality assurance management. The second sampling phase (two months) evaluated the effect of the revised cleaning and disinfection schemes, and also included the examination of additional difficult to clean localizations of the processing environment. In this second phase, Listeria were no longer found in samples from slicers, conveyor belts, or products. However, L. monocytogenes were still detected sporadically in environmental samples (e.g. on water hoses), and the intensified examination identified the inside of a bread-feeding machine as further problem area. The four $L$. monocytogenes strains from the bread-feeding machine all belonged to the predominant genotype (Rep PCR profile a, PFGE profile A) and were obtained during the first two visits. After revision of the cleaning and disinfection scheme of this machine, Listeria were no longer found. Hence, the implementation of the revised cleaning and disinfection procedures effectively improved the Listeria situation in this ready-to-eat food processing plant. 
An efficient food safety and hygiene concept of a food business operator must involve basic hygiene measures (good hygiene and manufacturing practices, including adequate cleaning and disinfection procedures), as well as product- and production-specific preventive measures in accordance with the HACCP principles (Sperber, 2005; Untermann, 1999; WHO, 1998). The results of the present study emphasize the importance of adequate cleaning and disinfection procedures in order to avoid L. monocytogenes becoming established in processing environments and thus posing a threat of product contamination. Furthermore, continuous environmental monitoring schemes for L. monocytogenes are of major importance to identify potential contamination sources and as an early warning system for food business operators, especially in food-processing plants with low L. monocytogenes prevalence in their food products.

\section{References}

Allerberger, F., \& Wagner, M. (2010). Listeriosis: a resurgent foodborne infection. Clinical Microbiology and Infection, 16, 16-23.

Anonymous (2005). Commission Regulation (EC) No 2073/2005 of 15 November 2005 on microbiological criteria for foodstuffs. Official Journal of the European Union, L338.

Benjamin, M. M., \& Datta, A. R. (1995). Modified pulsed field gel electrophoresis technique using Pefabloc $^{\circledR}$ SC for analyzing Listeria monocytogenes DNA. Biochemica, 2, 30-31.

Brosch, R., Brett, M., Catimel, M., Luchansky J. B., Ojeniyi, B., \& Rocourt, J. (1996). Genomic fingerprinting of 80 strains from the WHO multicenter international typing study of Listeria monocytogenes via pulsed-field gel electrophoresis (PFGE). International Journal of Food Microbiology, 32, 343-355.

CDC, Centre for Disease Control and Prevention (2002). Public health dispatch: outbreak of listeriosis - northeastern United States, 2002. Morbidity and Mortality Weekly Report, 51, 950-951.

CDC, Centre for Disease Control and Prevention (2009). Preliminary FoodNet data on the incidence of infection with pathogens transmitted commonly through food - 10 states, 2008. Morbidity and Mortality Weekly Report, 58, 333-338. 
Chou, C. H., \& Wang, C. (2006). Genetic relatedness between Listeria monocytogenes isolates from seafood and humans using PFGE and REP-PCR. International Journal of Food Microbiology, 110, 135-148.

Dawson, S. J., Evans, M. R., Willby, D., Bardwell, J., Chamberlain, N., \& Lewis, D. A. (2006). Listeria outbreak associated with sandwich consumption from a hospital retail shop, United Kingdom. Euro Surveillance, 11, 89-91.

Di Bonaventura, G., Piccolomini, R., Paludi, D., D'Orio, V. D., Vergara, A., Conter, M., \& Ianieri, A. (2008). Influence of temperature on biofilm formation by Listeria monocytogenes on various food-contact surfaces: relationship with motility and cell surface hydrophobicity. Journal of Applied Microbiology, 104, 1552-1561.

Doganay, M. (2003). Listeriosis: clinical presentation. FEMS Immunology and Medical Microbiology, 35, 173-175.

EFSA, European Food Safety Authority (2010). Community summary report on trends and sources of zoonoses, zoonotic agents and food-borne outbreaks in the European Union in 2008. The EFSA Journal, 1496.

Jemmi, T., Pak, S. I., \& Salman, M. D. (2002). Prevalence and risk factors for contamination with Listeria monocytogenes of imported and exported meat and fish products in Switzerland, 1992-2000. Preventive Veterinary Medicine, 54, 25-36.

Jemmi, T., \& Stephan, R. (2006). Listeria monocytogenes: food-borne pathogen and hygiene indicator. Revue Scientifique et Technique (International Offic e of Epizootics), $25,571-580$.

Jeršek, B., Gilot, P., Gubina, M., Klun, N., Mehle, J., Tcherneva, E., Rijpens, N., \& Herman, L. (1999). Typing of Listeria moncytogenes strains by repetitive element sequence-based PCR. Journal of Clinical Microbiology, 37, 103-109.

Kerr, K. G., Birkenhead, D., Seale, K., Major, J., \& Hawkey, P. M. (1993). Prevalence of Listeria spp. on the hands of food workers. Journal of Food Protection, 56, 525-527.

Lin, C. M., Takeuchi, K., Zhang, L., Dohm, C. B., Meyer, J. D., Hall, P. A., \& Doyle, M. P. (2006). Cross-contamination between processing equipment and deli meats by Listeria monocytogenes. Journal of Food Protection, 69, 71-79.

Little, C. L., Barrett, N. J., Grant, K., \& McLauchlin, J. (2008). Microbiological safety of sandwiches from hospitals and other health care establishments in the United Kingdom with a focus on Listeria monocytogenes and other Listeria species. Journal of Food Protection, 71, 309-318. 
Little, C. L., Sagoo, S. K., Gillespie, I. A., Grant, K., \& McLauchlin, J. (2009). Prevalence and level of Listeria monocytogenes and other Listeria species in selected retail ready-to-eat foods in the United Kingdom. Journal of Food Protection, 72, 1869-1877.

Liu, D., Lawrence, M. L., Wiedmann, M., Gorski, L., Mandrell, R. E., Jerald Ainsworth, A., \& Austin, F. W. (2006). Listeria monocytogenes subgroups IIIA, IIIB, and IIIC delineate genetically distinct populations with varied pathogenic potential. Journal of Clinical Microbiology, 44, 4229-4233.

Lukinmaa, S., Miettinen, M., Nakari U. M., Korkeala, H., \& Siitonen, A. (2003). Listeria monocytogenes isolates from invasive infections: variation of sero- and genotypes during an 11-year period in Finland. Journal of Clinical Microbiology, 41, 1694-1700.

Martinez, I., Rørvik, L. M., Brox, V., Lassen, J., Seppola, M., Gram, L., \& FonnesbechVogel, B. (2003). Genetic variability among isolates of Listeria monocytogenes from food products, clinical samples and processing environments, estimated by RAPD typing. International Journal of Food Microbiology, 84, 285-297.

Mead, P. S., Slutsker, L., Dietz, V., McCaig, L. F., Bresee, J. S., Shapiro, C., Griffin, P. M., \& Tauxe, R. V. (1999). Emerging Infectious Diseases, 5, 607-625.

Montville, R., Chen, Y., \& Schaffner, D. W. (2001). Glove barriers to bacterial crosscontamination between hands to food. Journal of Food Protection, 64, 845-849.

Norton, D. M., McCamey, M. A., Gall, K. L., Scarlett, J. M., Boor, K. J., \& Wiedmann, M. (2001). Molecular studies on the ecology of Listeria monocytogenes in the smoked fish processing industry. Applied and Environmental Microbiology, 67, 198205.

Nufer, U., Stephan, R., \& Tasara, T. (2007). Growth characteristics of Listeria monocytogenes, Listeria welshimeri and Listeria innocua strains in broth cultures and a sliced bologna-type product at 4 and $7^{\circ} \mathrm{C}$. Food Microbiology, 24, 444-451.

Parihar, V. S., Lopez-Valladares, G., Danielsson-Tham, M. L., Peiris, I., Helmersson, S., Unemo, M., Andersson, B., Arneborn, M., Bannerman, E., Barbuddhe, S., Bille, J., Hajdu, L., Jacquet C., Johansson, C., Löfdahl, M., Möllerberg G., Ringberg, H., Rocourt, J., Tjernberg, I., Ursing, J., Henriques-Normark, B., \& Tham, W. (2008). Characterization of human invasive isolates of Listeria monocytogenes in Sweden 1986-2007. Foodborne Pathogens and Disease, 5, 755-761. 
Pesavento, G., Ducci, B., Nieri, D., Comodo, N., \& Lo Nostro, A. (2010). Prevalence and antibiotic susceptibility of Listeria spp. isolated from raw meat and retail foods. Food Control, 21,708-713.

Rørvik, L. M., Aase, B., Alvestad, T., \& Caugant, D. A. (2000). Molecular epidemiological survey of Listeria monocytogenes in seafoods and seafoodprocessing plants. Applied and Environmental Microbiology, 66, 4779-4784.

Sheen, S., \& Hwang, C. A. (2008). Modeling transfer of Listeria monocytogenes from slicer to deli meat during mechanical slicing. Foodborne Pathogens and Disease, 5, 135-146.

Sperber, W. H. (2005). HACCP does not work from farm to table. Food Control, 16, 511-514.

Swaminathan, B., \& Gerner-Smidt, P. (2007). The epidemiology of human listeriosis. Microbes and Infection, 9, 1236-1243.

Tasara, T., \& Stephan, R. (2006). Cold stress tolerance of Listeria monocytogenes: a review of molecular adaptive mechanisms and food safety implications. Journal of Food Protection, 69, 1473-1484.

Tolvanen, R., Lundén, J., Hörman, A., \& Korkeala, H. (2009). Pilot-scale continuous ultrasonic cleaning equipment reduces Listeria monocytogenes levels on conveyor belts. Journal of Food Protection, 72, 408-411.

Untermann, F. (1999). Food safety management and misinterpretation of HACCP. Food Control, 10, 161-167.

Varma, J. K., Samuel, M. C., Marcus, R., Hoekstra, R. M., Medus, C., Segler, S., Anderson, B. J., Jones, T. F., Shiferaw, B., Haubert, N., Megginson, M., McCarthy, P. V., Graves, L., Van Gilder, T., \& Angulo, F. J. (2007). Listeria monocytogenes infection from foods prepared in a commercial establishment: a case-control study of potential sources of sporadic illness in the United States. Clinical Infectious Disease, 44, 521-528.

Vázquez-Boland, J. A., Kuhn, M., Berche, P., Chakraborty, T., Domínguez-Bernal, G., Goebel, W., González-Zorn, B., Wehland, J., \& Kreft, J. (2001). Listeria pathogenesis and molecular virulence determinants. Clinical Microbiology Reviews, 14, 584-640.

Vorst, K. L., Todd, E. C., \& Rysert, E. T. (2006). Transfer of Listeria monocytogenes during mechanical slicing of turkey breast, bologna, and salami. Journal of Food Protection, 69, 619-626. 
Ward, T. J., Gorski, L., Borucki, M. K., Mandrell, R. E., Hutchins, J., \& Pupedis, K. (2004). Intraspecific phylogeny and lineage group identification based on the prfA virulence gene cluster of Listeria monocytogenes. Journal of Bacteriology, 186, 4994-5002.

Warriner, K., \& Namvar, A. (2009). What is the hysteria with Listeria? Trends in Food Science \& Technology, 20, 245-254.

WHO, World Health Organization (1998). Guidance on regulatory assessment of HACCP. Report of a joint FAO/WHO consultation on the role of government agencies in assessing HACCP. WHO Document WHO/FNU/FOS/98.5. Geneva, Switzerland.

Wilson, I. G. (1996). Occurrence of Listeria species in prepacked retail sandwiches. Epidemiology and Infection, 117, 89-93.

Wong, S., Street, D., Delgado, S. I., \& Klontz, K. C. (2000). Recalls of foods and cosmetics due to microbial contamination reported to the U.S. Food and Drug Administration. Journal of Food Protection, 63, 1113-1116.

Wulff, G., Gram, L., Ahrens, P., \& Fonnesbech-Vogel, B. (2006). One group of genetically similar Listeria monocytogenes strains frequently dominates and persists in several fish slaughter- and smokehouses. Applied and Environmental Microbiology, 72, 4313-4322. 


\section{Tables}

\section{Table 1}

Distribution of Listeria positive samples from the processing environment, ingredients, and final products of a sandwich-producing plant in the first sampling phase (November 2008 to July 2009).

\begin{tabular}{lccc}
\hline & $\begin{array}{c}\text { No. of } \\
\text { samples }\end{array}$ & $\begin{array}{c}\text { No. (\%) of } \\
\text { L. monocytogenes } \\
\text { positive samples }\end{array}$ & $\begin{array}{c}\text { No. (\%) of Listeria } \\
\text { spp. positive } \\
\text { samples }\end{array}$ \\
\hline $\begin{array}{l}\text { Equipment of processing lines } \\
\text { During working process }\end{array}$ & 1192 & $46(3.9)$ & $1(0.1)$ \\
$\begin{array}{l}\text { After cleaning and } \\
\text { disinfection }\end{array}$ & 219 & $2(0.9)$ & ND $^{\mathrm{a}}$ \\
$\begin{array}{l}\text { Environment } \\
\begin{array}{l}\text { During working process } \\
\text { After cleaning and } \\
\text { disinfection }\end{array}\end{array}$ & 307 & $13(4.2)$ & $\mathrm{ND}$ \\
$\begin{array}{l}\text { Ingredients } \\
\mathrm{b}\end{array}$ & 61 & $3(4.9)$ & $\mathrm{ND}$ \\
\hline
\end{tabular}

${ }^{a} \mathrm{ND}$, not detected.

${ }^{\mathrm{b}}$ Ingredients pre-handled in the examined plant. 


\section{Table 2}

Characterization of L. monocytogenes strains isolated from the processing environment.

\begin{tabular}{|c|c|c|c|c|c|c|c|}
\hline & Origin & $\begin{array}{l}\text { No. of } \\
\text { strains }\end{array}$ & $\begin{array}{l}\text { Sampling } \\
\text { phase }^{\mathrm{a}}\end{array}$ & $\begin{array}{l}\text { Sero- } \\
\text { type }\end{array}$ & $\begin{array}{l}\text { - Genetic } \\
\text { lineage }\end{array}$ & $\begin{array}{c}\text { Rep } \\
\text { PCR } \\
\text { profile }\end{array}$ & $\begin{array}{l}\text { PFGE } \\
\text { profile }\end{array}$ \\
\hline \multicolumn{8}{|l|}{ Equipment } \\
\hline \multirow{5}{*}{$\begin{array}{l}\text { During working } \\
\text { process }\end{array}$} & Slicers & 27 & 1 & $1 / 2 \mathrm{a}$ & II & $\mathrm{a}$ & A \\
\hline & Conveyor belts & 11 & 1 & $1 / 2 \mathrm{a}$ & II & $\mathrm{a}$ & A \\
\hline & Tables & 5 & 1 & $1 / 2 \mathrm{a}$ & II & $\mathrm{a}$ & A \\
\hline & Spattles & 2 & 1 & $1 / 2 \mathrm{a}$ & II & $\mathrm{a}$ & $\mathrm{A}$ \\
\hline & Gloves & 1 & 1 & $1 / 2 \mathrm{a}$ & II & $\mathrm{a}$ & A \\
\hline \multirow[t]{3}{*}{$\begin{array}{l}\text { After cleaning } \\
\text { and disinfection }\end{array}$} & $\begin{array}{l}\text { Bread feeding } \\
\text { machine }\end{array}$ & 4 & 2 & $1 / 2 \mathrm{a}$ & II & $\mathrm{a}$ & $\mathrm{A}$ \\
\hline & Conveyor belt & 1 & 1 & $1 / 2 \mathrm{a}$ & II & $\mathrm{a}$ & A \\
\hline & Slicer & 1 & 1 & $1 / 2 \mathrm{a}$ & II & $\mathrm{a}$ & A \\
\hline \multicolumn{8}{|l|}{ Environment } \\
\hline \multirow{9}{*}{$\begin{array}{l}\text { During working } \\
\text { process }\end{array}$} & Water hoses & 3 & 1 & $1 / 2 b$ & $\mathrm{I}$ & $\mathrm{b}$ & B \\
\hline & Air blow-guns & 2 & 1 & $1 / 2 \mathrm{a}$ & II & $\mathrm{a}$ & A \\
\hline & Floors & 2 & 1 & $1 / 2 \mathrm{a}$ & II & c & $\mathrm{C}$ \\
\hline & Floor & 1 & 1 & $1 / 2 \mathrm{a}$ & II & a & $\mathrm{A}$ \\
\hline & Glove dispenser & 1 & 1 & $1 / 2 \mathrm{a}$ & II & $\mathrm{a}$ & A \\
\hline & Squeegee & 1 & 1 & $1 / 2 \mathrm{a}$ & II & $\mathrm{a}$ & A \\
\hline & Drain & 1 & 1 & $1 / 2 \mathrm{a}$ & II & C & $\mathrm{C}$ \\
\hline & Squeegee & 1 & 1 & $1 / 2 \mathrm{a}$ & II & c & $\mathrm{C}$ \\
\hline & Shelf & 1 & 1 & $1 / 2 \mathrm{a}$ & II & c & $\mathrm{C}$ \\
\hline \multirow{5}{*}{$\begin{array}{l}\text { After cleaning } \\
\text { and disinfection }\end{array}$} & Water hose & 1 & 1 & $1 / 2 \mathrm{a}$ & II & $\mathrm{a}$ & A \\
\hline & Air blow-gun & 1 & 1 & $1 / 2 \mathrm{a}$ & II & c & $\mathrm{C}$ \\
\hline & Water hose & 1 & 1 & $1 / 2 \mathrm{a}$ & II & $\mathrm{c}$ & $\mathrm{C}$ \\
\hline & Drain & 1 & 2 & $1 / 2 \mathrm{a}$ & II & C & $\mathrm{C}$ \\
\hline & Water hose & 1 & 2 & $1 / 2 \mathrm{a}$ & II & c & $\mathrm{C}$ \\
\hline
\end{tabular}

a 1 , first sampling phase (November 2008 to July 2009); 2, second sampling phase (October to November 2009). 


\section{Table 3}

Characterization of L. monocytogenes strains isolated from ingredients and final products.

\begin{tabular}{|c|c|c|c|c|c|c|}
\hline Origin & $\begin{array}{l}\text { No. of } \\
\text { strains }\end{array}$ & $\begin{array}{l}\text { Sampling } \\
\text { phase }^{\mathrm{a}}\end{array}$ & Serotype & $\begin{array}{l}\text { Genetic } \\
\text { lineage }\end{array}$ & $\begin{array}{c}\text { Rep } \\
\text { PCR } \\
\text { profile }\end{array}$ & $\begin{array}{l}\text { PFGE } \\
\text { profile }\end{array}$ \\
\hline Sliced salmon ${ }^{\mathrm{b}}$ & 4 & 1 & $1 / 2 a$ & II & $\mathrm{a}$ & $\mathrm{A}$ \\
\hline $\begin{array}{l}\text { Tuna } \\
\text { sandwiches }\end{array}$ & 3 & 1 & $1 / 2 \mathrm{a}$ & II & c & $\mathrm{C}$ \\
\hline Egg sandwiches & 3 & 1 & $1 / 2 \mathrm{a}$ & II & $\mathrm{a}$ & $\mathrm{A}$ \\
\hline Sliced salmon ${ }^{\mathrm{b}}$ & 2 & 1 & $1 / 2 b$ & I & $\mathrm{f}$ & $\mathrm{F}$ \\
\hline Sliced salmon ${ }^{\mathrm{b}}$ & 1 & 1 & $1 / 2 a$ & II & d & $\mathrm{D}$ \\
\hline Meat sandwich & 1 & 1 & $1 / 2 a$ & II & a & $\mathrm{A}$ \\
\hline Meat sandwich & 1 & 1 & $1 / 2 b$ & I & e & $\mathrm{E}$ \\
\hline Sliced ham ${ }^{\mathrm{b}}$ & 1 & 1 & $1 / 2 \mathrm{a}$ & II & a & $\mathrm{A}$ \\
\hline
\end{tabular}

${ }^{\text {a }} 1$, first sampling phase (November 2008 to July 2009).

${ }^{\mathrm{b}}$ Sliced in the examined plant. 


\section{Acknowledgments}

An dieser Stelle möchte ich mich bei all denjenigen bedanken, die zum Gelingen dieser Arbeit beigetragen haben.

Besonderer Dank geht an:

Herrn Prof. Dr. Roger Stephan, Institut für Lebensmittelsicherheit und -hygiene, Vetsuisse Fakultät Universität Zürich, für die Möglichkeit zur Erstellung dieser Dissertation, das Fördern und Fordern, die wertvolle Unterstützung in allen Belangen sowie die Übernahme des Referates.

Prof. Dr. Maria Fredriksson-Ahomaa, University of Helsinki, für die Übernahme des Korreferates.

Herrn PD Dr. Claudio Zweifel, Institut für Lebensmittelsicherheit und -hygiene, Vetsuisse Fakultät Universität Zürich, für die stets gewährte Unterstützung von Beginn bis zum Abschluss meiner Arbeit, die konstruktive und kritische Anleitung beim Schreiben sowie der Überarbeitung des Manuskripts, für unzählige Lacher, anregende Diskussionen und die gute Zeit.

Frau Ursula Kuhn, Herrn Urs Leibinger und Herrn M. Bänziger, Bell AG, Schafisheim, für die Ermöglichung der Arbeit in ihrem Betrieb, die Unterstützung und Mithilfe bei den Probenentnahmen.

Herrn David Hauser, Bell AG, Schafisheim, für die konstruktive Zusammen- und Mitarbeit und sein grosses Engagement.

Frau Nicole Giezendanner für die immense Hilfe bei der Durchführung der Rep PCR sowie bei allen Laborfragen.

Frau Corinna Seibert und dem ganzen Laborteam für die Herstellung der Nährmedien.

Meine Mitdissertantinnen für die zahlreichen witzigen Stunden, die gegenseitige Unterstützung mit Rat und Tat und dem Gewinn von Freundschaften.

Das gesamte ILS-Team für das angenehme Arbeitsklima.

Meine Verwandten für die immer offenen Arme und zahlreichen Kost- und Logismöglichkeiten.

Meine grossartige Familie, die mir diesen Weg überhaupt erst ermöglicht hat.

Meinen Thomas als ruhendem Pol und Fels in der Brandung. 


\section{Lebenslauf}

Name

Geburtsdatum

Geburtsort

Nationalität

Heimatort

1989 - 1996

1996 - 1999

1999 - 2003

2003

$2003-2008$

2008

$2008-2010$

seit 2008

3. Mai 2010
Simona, Blatter

8. Juni 1983

Niederried bei Interlaken, BE

Schweiz

Niederried bei Interlaken, BE

Primarschule Niederried bei Interlaken, BE

Sekundarschule Interlaken, BE

Gymnasium Interlaken, BE

Erlangung der Maturität am Gymnasium Interlaken, BE

Studium der Veterinärmedizin an der Vetsuisse-Fakultät Universität Bern, Schweiz

Erlangung des Diploms für Tierärzte an der Vetsuisse-Fakultät Universität Bern, Schweiz

Dissertation am Institut für Lebensmittelsicherheit und -hygiene der Vetsuisse-Fakultät Universität Zürich, Schweiz

Assistentin in der Kleintierpraxis Dr. med. vet. Christoph Rüedi, Laupen, BE 